\title{
Consumer Perceptions towards Online Retailing in Botswana: A Case Study of the University of Botswana
}

\author{
Mashoko T. Dzimiri, Katlego A. Thamage, Mogotsinyana Mapharing, Elang Basuhi, Ishmael Radikoko \\ University of Botswana, Department of Accounting and Finance \\ mashokodzimiri@gmail.com; thamagekatlego@gmail.com; mogotsinyana.mapharing@mopipi.ub.bw \\ basuhie@ub.ac.bw; radikokoi@ub.ac.bw
}

\begin{abstract}
The study was premised on assessing the existing customer perceptions towards online retailing in Botswana. In particular, the study used University of Botswana staff and students as a case study. Data for this study was collected through questionnaires given to students and staff of the University of Botswana. Descriptive statistics and Independent t-tests were used to analyse the results. The results from this study indicate that consumers in the University of Botswana utilise traditional shopping more than online shopping. Though accessible by people of all income, online shopping is perceived to be risky and needs a skillful internet user. Delivery concerns, technology specific innovativeness and financial risk were found to negatively influence online shopping behavior. On the other hand, subjective norms, good return policy and convenience were found to positively influence online shopping behavior. The findings from this study provide a first glance at existing customer perceptions in Botswana which should encourage further and more extensive research to yield more generalizable results that reflect consumer perceptions. Local retailers or businesses will find these results useful as these will help them narrow their focus on how to sway consumers to use their online shops.
\end{abstract}

Key words: consumer perceptions, online retailing, factors, descriptive analysis, University of Botswana

\section{Introduction}

The internet has without doubt been considered one of the 50 Greatest breakthroughs since the invention of the Wheel [1]. In that light, the internet has changed several aspects of human life particularly how we interact, learn and govern ourselves and especially how business is conducted[2]. A great example of such technological change in business conduct is the emergence of online retailing which started off as a mere alternative method of selling products. Consequently, it has grown phenomenally over the years from a feasible sales channel to a lucrative retail sector that is redefining the retail landscape. For example, through online retailing, traditional retail businesses have managed to tap into other markets beyond geographical limitations, reduce overhead costs, generate more revenues, increase market share and increase online presence [ $\underline{3}]$. Additionally, customers benefit more from the improved customer service delivered through online retailing.

The prominence of online retailing is especially evident in more developed countries particularly China and the United States. In 2014, the two countries jointly controlled 55\% of global internet retail sales, 
which in total were expected to top an astounding estimate of $\$ 22$ trillion with the figure being expected to grow in the following years[4]. Examples of such online retail businesses pioneering this exemplary performance included brick and mortar companies which adopted online retailing such as Wal-Mart stores Inc. (USA) and Tmall (China); as well as self-operating website businesses such as Amazon (USA) and Alibaba (China), all of which earned billions in remarkable sales and revenue performance through online retailing $[\underline{5}, \underline{6}]$. Further to that, [] posits that online retailing shops have substantially benefitted from this sales alternative, such that companies such as Amazon.com have achieved superior performance making it the $8^{\text {th }}$ largest retailer in the world.

In the African context, the ever increasing development in internet connectivity infrastructure and online usage has increased phenomenally in developing countries, particularly those in the African continent. The number of internet users in Africa was estimated to be close to 453 million, conveying an astounding growth rate of 9,942\% from 2000 to 2017 as at 31 December 2017 [8]. Such increase in internet usage has led to the recent adoption and emergence of internet retailing albeit its infancy stage. Despite such, online retailing has been adopted by a majority of African countries such as Egypt, Nigeria, South Africa, Angola, and Kenya which stand as Africa's leaders in online retail, with a combined total online retail sales of close to $\$ 4$ billion [9] .

Early adopters of the online retailing concept include a majority of the top 10 retailers in Africa which happen to be notable brick and mortar companies such as Shoprite Holdings Ltd, Woolworths Holdings Ltd, and Pick $n$ Pay Stores Ltd. The three retailers performed exceptionally well in sales and revenue in 2013. Another interesting fact is these all originate from South Africa[9]. Notable online retail website companies such as Jumia, Kaymu and Konga have also seen prosperity in online retailing growing beyond their country of origin (Nigeria) and expanding across the African continent[9]. Similarly, internet usage in Botswana has significantly increased over the years due to much improvement in internet connectivity by government and internet providing companies. This is conveyed by $36.7 \%$ of the population using the internet[10]. By extension, the researchers intend to explore online retail usage perceptions in Botswana context. We extend on the conceptual model used by [11] in assessing factors affecting Indian consumers' online buying behavior by incorporating other perceptual dimensions such as demographics.

\subsection{Problem Statement}

Recently, companies in Botswana have started to adopt online retailing which includes Sefalana Holdings, which is the first brick and mortar retail group to launch an online shopping site in Botswana. Online shopping companies such as shop360 and Skymartbw (Pty) Ltd have also established themselves in an effort to pioneer and benefit from the prospect of online retailing in Botswana. However, despite such emergence of such promising online retailers, online usage statistics indicate that out of the entire internet user population in 2014, only $7.4 \%$ used the internet to purchase goods and services[10]. As a result, the key question is what are the factors influencing or deterring consumers to utilise online retailing stores in Botswana?

\subsection{Research Objectives}

The overall objective of this paper is to explore consumer perceptions on online retailing in Botswana. In particular, this study aims to:

1. Identify and assess the existing customer perceptions towards online retailing 
Mashoko T. Dzimiri, Katlego A. Thamage, Mogotsinyana Mapharing, Elang Basuhi, Ishmael Radikoko; Consumer Perceptions towards Online Retailing in Botswana: A Case Study of the University of Botswana, Transactions on Networks and Communications, Volume 6 No. 5, October (2018); pp: 70-91

\subsection{Significance of the Study}

The study is focused on the consumer perceptions towards online retailing among University of Botswana students and employees. As already outlined, online retailing is still at its infancy stage in Botswana. Nevertheless, Botswana retail businesses could greatly benefit from such a lucrative online presence. Therefore it is imperative that online retail businesses understand their target market in order to succeed in online retailing. Thus, this study aims to provide valuable insight into the perceptions that customers hold towards online retailing. Businesses can then use such valuable knowledge to better market themselves to their target market and increase their customer base, revenues and profitability. More importantly, the Botswana economy could greatly benefit from the success of these online businesses as this will provide needed tax revenue and thus contribute towards the GDP, promote diversity, and increase export presence in the global market.

This study is divided into five sections. Section 1 is the Introduction and section 2 covers Literature review. Methodology is covered in section 3 and section 4 covers the Analysis of data, findings and discussions. Meanwhile, conclusions and recommendations are covered in section 5.

\section{Literature Review}

\subsection{Theoretical Review}

The Theory of Planned Behaviour (TPB) has been used in prior studies to assess consumer perceptions and online retailing (Azjen, 1985, 1991; Azjen \& Fishbein, 1980), as cited in [11]. However, conceptual model proposed to assess perceptions of consumers towards online retailing in Botswana is the modified Theory of Planned Behavior (TPB). This conceptual framework was particularly used by [11] in their study assessing factors affecting Indian consumers' online buying behavior. The theory is appropriate for this study as it explains behaviors over which individuals have incomplete voluntary control. In other words, the theory predicts deliberate behavior due to the fact that behavior can be deliberate and planned [12] The conceptual model is presented in Figure 1.

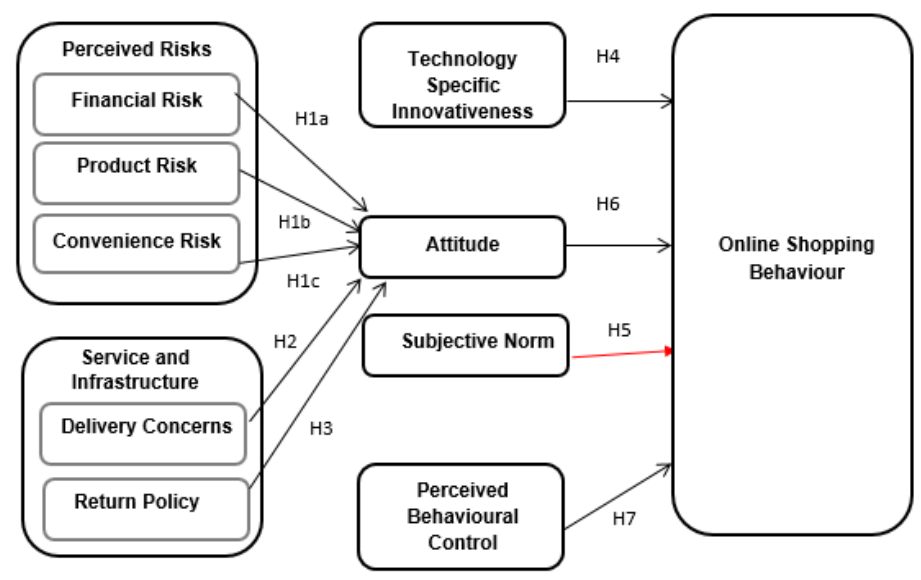

Source: Sinha \& Kim, 2012

Figure 1: Conceptual model of factors influencing Botswana shoppers' online shopping behavior 
This modified Theory of Planned Behavior assumes that online shopping behavior is influenced by several factors, the four most common being attitude, subjective norm, perceived behavioral control and technology specific innovativeness as discussed below:

Attitude: [11]), note that a consumer attitude towards performing a behavior has been proven as a strong predictor of behavior. The researchers further state that the attitude can be considered in several contexts which include customers' acceptance of the internet as a shopping channel, customer attitudes in preference of a specific internet retailer as well as attitude towards online shopping as a whole. In addition, [11]) indicates that consumer attitude is further influenced by other factors such as (1) perceived risks and (2) service and infrastructure.

A perceived risk refers to the nature and amount of risk perceived by a consumer in contemplating a particular purchase decision. Basically, this refers to all the risks the consumer considers in making the decision to purchase online. Key risks in the online retailing context include:

Financial risk: Risk involved in engaging in a financial transaction through the internet such as risk of being hacked, or being a victim of fraud etc.

Product risk: Risk involved in receiving the undesired product different from the one displayed on the online retailing stores.

Convenience risk: Referred to as the discontent arising from shopping via online retailing stores.

Service and infrastructural variables on the other hand includes all variables related to service and infrastructural deficiencies in the country that affect consumers' attitude towards online retailing.

Subjective norm: Subjective norms reflect a consumer's perceptions influenced significantly by others such as friends, family, authority figures and media [11].

Perceived behavioral control: Another influential factor in online consumer behavior, the perceived behavioral control accounts for consumers' perceptions in their ability to perform a given behavior [11]. Subsequently, this sheds light on the possible internal and external constraints which a consumer faces and which in turn affect their behavior towards online retailing.

Technology specific innovativeness: According to [11], this refers to the degree to which an individual is relatively earlier in adopting an innovation than other members of their system. Basically, this conveys the extent to which an individual goes outside their usual shopping routine and rather actively pursues engaging in new technological innovations.

Essentially, the modified theory of Planned Behavior though used in a different but similar research is a feasible conceptual framework for this study which is aimed at evaluating the customer perceptions towards online retailing in Botswana. According to [13], perception is the first impression that an individual draws and on the basis of it selects and interprets information to form a meaningful picture of the world. Subsequently, as observed by the framework, perceptions play important role in influencing the attitudes as well as other factors crucial to motivating online consumer behavior as well as online shopping rate $[14,15]$.

\subsection{Empirical review}

This sub-section explores previous empirical studies carried out on the perceptions of consumers on online retailing in other countries, and in particular, focusing on the factors identified in the conceptual 
Mashoko T. Dzimiri, Katlego A. Thamage, Mogotsinyana Mapharing, Elang Basuhi, Ishmael Radikoko; Consumer Perceptions towards Online Retailing in Botswana: A Case Study of the University of Botswana, Transactions on Networks and Communications, Volume 6 No. 5, October (2018); pp: 70-91

framework(attitude, subjective norms, perceived behavioral control, technology specific innovativeness) and any other factors identified in relevant literature.

\subsubsection{Attitude}

Attitude towards a behavior refers to the degree to which a person has a favorable or unfavorable evaluation of the behavior in question[16]. In the context of online shopping, [17]consider attitudes to be the consumers' positive or negative feelings related to accomplishing the purchasing behavior on the internet. A study by [18] highlights that an individual's shopping choice is influenced by four key factors which they identify to be motivation, perception, learning and beliefs, and attitudes. Attitude thus serves as a bridge between consumers' background characteristics and the consumption that satisfies their needs[19]. [11] in their modified version of the Theory of Planned behavior, convey that attitude can be influenced by the following key perception factors, in particular, (1)perceived risk and (2) Service and Infrastructure variables:

Perceived risk: [20] defines risk as the measure of probability and the weight of undesired consequences. [21] defines risk as the effect of uncertainty on objectives. [22] identifed perceived risk to be the degree to which a person expresses uncertainty about a service or good and particularly the consequence. In the context of online retailing, [11] consider perceived risk as the risk or uncertainty inherent in a decision to purchase from online retailers. Perceived risk is considered to directly affect online consumer behavior and their intention to purchase [23-26]. Thus, in doing so, the researchers convey that there is a negative relationship or correlation between consumer perceived risk and consumer intention to purchase online. This indicates that when consumer perceived risk is high, the consumer intention to purchase online is low [23]. As noted in [27]," risk is a word that has various meanings to various people". Therefore, due to the differing viewpoints of perceived risk, there is need to contextualize the risk to reflect the key factors being assessed. Possibly in view of this and to best aid the purpose of their study, [11] broke down perceived risk into 3 key subdimensions which are (1)finacial risk, (2) product risk and (3) convenience risk as reviewed below:

Financial Risk: defined as the likelihood of suffering a monetary loss from a purchase [28, 29]. [30] note that there are different reasons why online shoppers may suffer financial loss such as price and security.

Price can be defined as the consumer's perceptual representation or subjective perception of the objective price of the product[31]. The promise of greater savings is one of the major motives drawing consumers to shop online[32]. According to [33] price is a critical factor in customers using online shopping. Online shoppers find it difficult to determine whether the price offered by online retailing sites is indeed the lowest at that point in time [30]. [34] further add that the perception of such financial risk explains why online shoppers abandon carts. Additional costs associated with shopping online such as shipping and delivery costs had been also identifed to deter consumers from shopping online[35].

On the other hand, [36] highlights that security is another critical factor for any success to occur in online retailing. The statement was further cemented by [37][37][37]who state that without proper security, online shoppers would lack significant confidence in using online shopping which would ultimately affect these online retailing stores. [30] highlights that the main security concern and cause of financial loss highlighted was credit card fraud. [38] shares this view as they highlight that the primary reason indicated by most shoppers who preferred not to shop online was due to the fear of revealing personal credit card 
information to retailers over the internet. The view is further emphasized by [39], whose findings indicate that close to $70 \%$ of the US internet shopping population limit their online purchases because of concerns related to the privacy and safety of their personal information. Despite privacy concerns being frequently cited for not purchasing online, it did not have any significant influence on purchasing behaviors suggesting that privacy concerns may not deter shopping among current online shoppers[40] .

Further, findings from previous research indicate that perceived financial risk is the most consistent predictor of internet patronage behavior [40].[40] further indicate that perceived financial risk was a significant predictor for searching with intent to buy, amount spent on the Web and frequency of purchasing online. Thus, this further conveys that financial risk is likely to deter Internet shoppers from initiating the Internet shopping process or cause them to be more selective regarding which online retailing sites they patronize as well as further reducing the amount they could have spent had they not been concerned with this financial risk [40] .

Product Risk also known or considered as performance risk, is defined as the probability of the item failing to meet the performance requirements originally intended[41]. [30]indicates that product risk has been reported as the most frequently cited reason for not shopping online. Furthermore, product risk has been identifed to have significant impact on the frequency of purchasing online[40].[40] note that product performance risk was frequently cited as the reason for not purchasing online, however the impact of that risk was limited to only the frequency of purchasing online. The researchers further indicate that the limited effect of product risk on shopping behaviors suggests that concerns regarding product performance may be less of a deterrent to internet patronage behavior among current Internet shoppers than previously thought [40].

Convenience risk: A distinct characteristic of online shopping is its convenience and it has been found to be the major motive for consumers to shop online [42, 43].[23] defines convenience risk as the risk associated with how the consumer perceives the delay in delivery time, the quality delivered, the after sale services and the relationship with the online vendors. However, out of the noted key points, the risk is mostly focused on the quality provided through the online service [23]. Convenience risk was noted to be a significant predictor of the frequency of searching with intent to buy and frequency of purchasing online but not the amount spent on the web [40]. This suggests some Internet shoppers may hesitate to shop online due to concerns about inconvenience or delays in receiving merchandise [40].

Service and infrastructure variables: This refers to the additional challenges facing e-commerce diffusion particularly in developing countries such as internet connectivity [11]. According to [11], developing countries such as India face challenges such as lack of telecomunications infrastructure throughout the country which ultimately affects use and support of online retailing stores. Further, there are Delivery Concerns which encompasses all the concerns associated with delivery of the product ordered, such as shipping fees, delayed delivery and/or not receiving a product ordered [11]. The researchers further highlight that in India this has proven to be a significant concern as postal couriers are unreliable and relatively risky forcing online shoppers to choose the government postal courier which is more reliable. However, this result in increased costs as it is more expensive. In addition to that, there are issues with Return Policy. [36] in their study note that online retailers should have refund policies to convince online consumers that they easily return products and get refunds if they are dissatisfied or exchange products for free within a reasonable timeframe. However, the ease of return policies is frequently cited as a concern to online shoppers[44]. 
Mashoko T. Dzimiri, Katlego A. Thamage, Mogotsinyana Mapharing, Elang Basuhi, Ishmael Radikoko; Consumer Perceptions towards Online Retailing in Botswana: A Case Study of the University of Botswana, Transactions on Networks and Communications, Volume 6 No. 5, October (2018); pp: 70-91

\subsubsection{Subjective norms}

[23] note that consumer buying decisions are highly affected by the opinions and decisions of others. As was further cited by [45], word-of-mouth marketing is a fundamental part of the marketing process as consumers greatly rely on advice of other people when they make potential purchase decisions.

\subsubsection{Perceived behavioral control}

This refers to the additional construct added to extend the Theory of Reasoned Action (TRA) into the Theory of Planned Behavior as a determinant of behavioral intention and behavior [11]. Perceived behavioral control refers to individuals' perceptions of their ability to perform a given behavior[46]. Such perceptions can influence the behavior directly or indirectly through behavioral intentions[47]. [48] note that consumer willingness and preference for adopting online shopping was positively related to income, household size and innovativeness. This correlates with the view by [11] that perceived behavioral control reflects perceptions of internal constraints (self-efficacy) as well as external constraints on behavior like availability of resources. In addition, the researchers indicate that unless control over a behavior exists, intentions will not be a sufficient as the predictor of the behavior[47].[49] highlights that Perceived Behavioral Control directly affects online shopping behavior.

\subsubsection{Technology specific innovativeness (TSI)}

[48] posits that consumer willingness to and preference for adopting online shopping was positively related to innovativeness amongst other factors. [11] further highlights that Technology specific innovativeness conveys the extent to which an individual goes outside their usual shopping routine and rather actively pursues engaging in new technological innovations. However in order to use online shopping, individuals require necessary computer skills and thus those uncomfortable with the use of a computer will likely find shopping at a traditional store easier and faster than through online retailing sites[50].

\subsubsection{Other perceptual dimensions Satisfaction:}

[51] found consumer satisfaction as essential in order to gain better financial performance of services in a company which is considered the second most important thing to such companies, next to gaining profit.

\section{Demographics:}

[52] established that motivational factors as well as age and gender impacted the likelihood of online purchasing.

Gender is an important factor in explaining several differences in consumers' shopping behaviors and perception of goods [53]. [52] highlight that older males were found to have the highest online purchasing behavior. This might be explained further by [40] who found that women perceived more financial risks associated with online shopping than men. Women also portrayed more privacy concerns and perceived risks, all which may be viewed as reasons explaining the unfavorable attitude by women towards online shopping [54, 55]. However, [56] concluded that gender had no significant influence on shopping behavior.

In terms of age, [52] highlights that older internet users were more likely to buy online as compared to younger users. This might be better explained by [57] who notes that internet shoppers tend to be older 
and have high levels of income. This is so because younger users often do not have credit cards and thus are unable to purchase online[58]. Further, older generations were found to comparatively be more likely to purchase because they spend less time by searching for fewer products [59]. However, [59] further highlighted that younger internet users spend more time searching for many products as much as they purchased almost the same quantity of products as older generations. Meanwhile, [40] note that age was found to be a predictor of amount spent online, however did not predict other shopping behaviors.

Experience is viewed as a complex and developing structure as there are no two exactly similar experiences, but there are various experiences perceived differently[60]. Experience in this case refers to undergoing or encountering online shopping. Intention to shop online is related to past purchasing experience and directly influences internet shopping behavior[50]. Such past online shopping experiences have been identified to have significant influence on purchasing intention [61, 62]. However, [63] conducted a study in Indonesia, the direct effect of experience on purchasing intention was found to be insignificant. However, [40] note that despite the potential impact of such demographical characteristics, they are found to have little consistent impact on online shopping behaviors.

Based on the reviewed literature, the following seven hypotheses were formulated;

$\mathrm{H} 1 \mathrm{a}$ : There is a negative relationship between financial risk and attitude towards online retailing

$\mathrm{H} 1 \mathrm{~b}$ : There is a negative relationship between product risk and attitude towards online retailing

H1c: There is a negative relationship between convenience risk and attitude towards online retailing

$\mathrm{H} 2$ : The fear of product delivery will negatively affect attitudes towards online shopping

H3: A good return policy will positively affect attitudes towards online shopping

$\mathrm{H}$ 4: There is a positive relationship between technology specific innovativeness (TSI) and online retailing

$\mathrm{H} 5$ : There is a positive relationship between subjective norms (opinion and decision of significant others such as relatives, friends, peers) and online retailing

H6: There is direct relationship between attitude and online retailing

H7a: Older generations are perceived to use more online retailing than younger ones

$\mathrm{H7b}$ : Males are perceived to use more online retailing than female counterparts

\section{Methodology}

The study adopted a positivism philosophy as credible data could only be derived through quantitative analysis of phenomena observed [64]. Due to the positivist nature of the research, a deductive approach was adopted. This approach represents the most common view of the relationship between theory and research and results received from this approach are developed through logical reasoning [65]. A survey was conducted using a questionnaire to collect data on consumer perceptions towards online retailing.

The target population for the study was the University of Botswana community. Thus a sample was taken comprising of university students and staff, academic and non-academic staff (administration staff). Justification for University of Botswana community was that:

i. Internet Access: The University of Botswana provided year-round unlimited internet and Wi-Fi connectivity to staff and students at the campus. 
Mashoko T. Dzimiri, Katlego A. Thamage, Mogotsinyana Mapharing, Elang Basuhi, Ishmael Radikoko; Consumer Perceptions towards Online Retailing in Botswana: A Case Study of the University of Botswana, Transactions on Networks and Communications, Volume 6 No. 5, October (2018); pp: 70-91

ii. Computer literate: The University of Botswana staff is highly qualified and proficient in the use of computers. Students during the first academic year must take an Information and Communication Technology course that provide sufficient basic understanding of how to use the computer and internet.

iii. Financial Resources: The salaries and wages for employees are credited into their bank accounts thus meaning that such employees all had either a debit or credit card. Students on the other hand, had debit cards made possible by the government sponsorship agreement which resulted in debit cards being issued to students in order to access their monthly allowance stipend.

Based on the gender proportions of the internet users population in Botswana which stood at 240871 males and 252913 females as at 31 December 2014 [8], a quota and convenient sampling technique was applied to determine the study sample. Using $0.01 \%$ proportion from each quota of the population the sample size of the study was determined. Effectively, meaning that 24 males and 26 females were selected to make up the study sample.

The time horizon for the study was a cross sectional one, as such this study was conducted once off and represented the consumer perceptions towards online retailing prevalent during the period April-May 2017.

The study used primary data that was collected using a questionnaire that had two sections, the first section being for the background information of respondents and second section having questions of their perceptions towards online retailing. They were closed ended questions based on Likert scale and respondents were asked to state their opinion or preference for in response to the particular question on a scale given.

IBM SPSS Statistics 24 software was used to analyse the data from the questionnaire through descriptive statistics, frequency tabulations, independent t-tests and as well as cross-tabulations.

\section{Empirical Findings and Discussion}

Background information of the respondents is shown on Table 1. A total of forty eight (48) questionnaires were returned by the respondents which was $96 \%$ response rate. In terms of respondents occupation 24 (50\%) were students whilst the other 24 (50\%) were university employees and in terms of their gender 25 (52.1\%) were male and $23(47.9 \%)$ were female. $52.08 \%$ of respondents fell within the $21-25$ age range followed by the 32 and above age group that had $39.58 \%$ of respondents whilst $26-32$ years and, 20 and under years both had $4.17 \%$ of respondents. The majority of the respondents, $52.08 \%$ earned a monthly income in the range $\mathrm{P} 1,000-\mathrm{P} 10,000$ followed by $41.67 \%$ of respondents that earned more than $\mathrm{P} 10$, 000 per month. Only $6.25 \%$ of the respondents earned a monthly income less than $\mathrm{P} 1,000$. 
Table 1 Background Information of Respondents

\begin{tabular}{lrr}
\hline & Number & \multicolumn{2}{l}{ Percentage } \\
\hline Gender & 25 & 52.10 \\
\hline Male & 23 & 47.90 \\
\hline Female & 48 & 100.00 \\
\hline Total & & \\
\hline Age & 2 & 4.17 \\
20 and under & 25 & 52.08 \\
\hline $21-25$ & 2 & 4.17 \\
\hline $26-32$ & 19 & 39.58 \\
\hline 32 and above & 48 & 100.00 \\
\hline Total & & \\
\hline Occupation & 24 & 50.00 \\
\hline Student & 24 & 50.00 \\
\hline Employed & 48 & 100.00 \\
\hline Total & & \\
\hline Monthly income & 3 & 6.25 \\
\hline Less than P1000 & 25 & 52.08 \\
\hline P1000-P10000 & 20 & 41.67 \\
\hline More than P10000 & 48 & 100.00 \\
\hline Total & & \\
\hline
\end{tabular}

\section{Perceptions of respondents regarding online retailing}

The perceptions of respondents regarding online retailing are depicted in Table 2. In particular, respondents were asked to state their degree of agreement of the identified statements regarding their perceptions. Out of the twenty six opinions evaluated from the respondents only two had means below the expected mean of 3 and these were "online shopping is for individuals with high income" and "online shopping is as secure as traditional shopping" with means of 2.75 and 2.88 respectively.

The overall mean of the respondents' perceptions was 3.63 and greater than the expected mean of 3 . Notably, "Purchasing through online only, on condition of good return policy" had the highest mean of 4.29 followed by "It is a great advantage to shop anytime of the day" with a mean of 4.17 . The other perceptions with means above 4 were "There is a broad selection of goods on the internet", "Local retailers should offer online shopping as an alternative" and "Trust online shops that have received positive reviews from the authority".

In order to generalize the perception of respondents, the twenty six perceptions were sub-divided into eight groups being convenience, product risk, financial risk, product delivery, technology specific innovativeness, return policy, social influence and overall view (attitude) towards online shopping. Social influence had the highest average mean of 3.97 in which respondents were agreeing that they trusted online shops with positive reviews from authorities, friends and family.

The three perceptions that were grouped together to represent "Financial risk" had an average mean of 3.54 above the expected average mean of 3. The respondents were not in agreement that online shopping was secure as compared traditional shopping with a mean of 2.88 . They preferred to pay cash on delivery as compared to using credit/debit cards when purchasing online purchases with a mean of 3.98. The respondents hesitated to disclose details of their debit/credit cards when making online purchases as confirmed by the mean of 3.75 . This shows that the respondents were afraid of the financial risk they 
Mashoko T. Dzimiri, Katlego A. Thamage, Mogotsinyana Mapharing, Elang Basuhi, Ishmael Radikoko; Consumer Perceptions towards Online Retailing in Botswana: A Case Study of the University of Botswana, Transactions on Networks and Communications, Volume 6 No. 5, October (2018); pp: 70-91

could face when purchasing online. Therefore hypothesis $\mathrm{H}_{1 \mathrm{a}}$ : is accepted which states that "There is a negative relationship between financial risk and attitude towards online retailing".

Respondents' perception towards product risk was determined by enquiring on the selection of goods on the internet, accuracy of products description and whether sufficient information was available to make a purchase decision. The average mean of product risk was 3.47 entailing that respondents agreed there was a broad selection of products with accurate descriptions and sufficient information to make a buy decision on the websites. Hypothesis $\mathrm{H}_{1 \mathrm{~b}}$ : is rejected which states that, "There is a negative relationship between product risk and attitude towards online retailing".

Table 2: Perceptions of respondents regarding online retailing

\begin{tabular}{|c|c|c|c|c|c|c|c|}
\hline & $\begin{array}{c}\text { Strongly } \\
\text { disagree }\end{array}$ & Disagree & Indifferent & Agree & $\begin{array}{l}\text { Strongly } \\
\text { Agree }\end{array}$ & Mean & Std. Dev \\
\hline \multicolumn{8}{|l|}{ Convenience } \\
\hline i) Shopping orline saves time & - & $6.3 \%$ & $25.09 \%$ & $35.4 \%$ & $33.3 \%$ & 3.96 & 0.922 \\
\hline i] It is a great advantoge to shop any time of the days & - & - & $18.8 \%$ & $45.8 \%$ & $35.4 \%$ & 4.17 & 0.724 \\
\hline iii) Online shopping reduces overall costs as compared to traditional shopping & - & 16.75 & $37.5 \%$ & 27.190 & $18.8 \%$ & 3.48 & 0.989 \\
\hline Average mean & & & & & & 3.87 & \\
\hline \multicolumn{8}{|l|}{ Product Risk } \\
\hline i) There is a broad selection of goods on the internet & - & $4.2 \%$ & $18.8 \%$ & $41.7 \%$ & $35.7 \%$ & 4.08 & 0.846 \\
\hline i] The description of products on internet are accurate & $2.1 \%$ & $18.8 \%$ & $50.0 \%$ & $20.8 \%$ & $8.3 \%$ & 3.15 & 0.899 \\
\hline iii) Available product information is sufficient to make a purchase & 6.350 & $18.8 \%$ & $35.4 \%$ & $29.2 \%$ & $10.4 \%$ & 3.19 & 1.065 \\
\hline Average mean & & & & & & 3.47 & \\
\hline \multicolumn{8}{|l|}{ Financial Risk } \\
\hline i) Online shopping is as secure as traditional shopping & $12.5 \%$ & $35.4 \%$ & $18.8 \%$ & $18.8 \%$ & $14.6 \%$ & 2.88 & 1.282 \\
\hline i] Hesitate to disclose credit/debit card detals during online shopping & $6.3 \%$ & $12.5 \%$ & $14.6 \%$ & $33.3 \%$ & $33.3 \%$ & 3.75 & 1.229 \\
\hline iii) Prefer cash on delivery than payment using credit/debit card & 2.195 & 16.75 & $14.6 \%$ & $14.6 \%$ & $52.1 \%$ & 3.98 & 1.246 \\
\hline Average mean & & & & & & 3.54 & \\
\hline \multicolumn{8}{|l|}{ Products delivery } \\
\hline i) Purchose online only if there is provision for home delivery & $2.1 \%$ & $14.6 \%$ & $22.9 \%$ & $35.4 \%$ & $25.0 \%$ & 3.67 & 1.078 \\
\hline i] Prefer to collect the product myself & $6.3 \%$ & $14.6 \%$ & $25.0 \%$ & $39.6 \%$ & $14.6 \%$ & 3.42 & 1.108 \\
\hline iii) Long time required for the delivery of products & $4.2 \%$ & $16.7 \%$ & $27.1 \%$ & $35.4 \%$ & $16.7 \%$ & 3.44 & 1.09 \\
\hline iv) Courier companies are reliable & 6.350 & $12.5 \%$ & $27.1 \%$ & $45.8 \%$ & $8.3 \%$ & 3.38 & 1.024 \\
\hline Average mean & & & & & & 3.48 & \\
\hline \multicolumn{8}{|l|}{ Technology specific innovativeness } \\
\hline i) Lock of experience in internet use & $2.1 \%$ & 16.75 & $31.3 \%$ & $29.2 \%$ & $20.8 \%$ & 3.50 & 1.072 \\
\hline i) Online shopping complex compored to traditional shopping & - & $16.7 \%$ & $31.3 \%$ & $35.4 \%$ & $16.7 \%$ & 3.52 & 0.967 \\
\hline iii) Several resources required for online shopping & - & $20.8 \%$ & 25.095 & $39.6 \%$ & $14.6 \%$ & 3.48 & 0.989 \\
\hline Average mean & & & & & & 3.50 & \\
\hline \multicolumn{8}{|l|}{ Refurn policy } \\
\hline i) Purchose through online only, on condition of good return policy & - & - & $16.7 \%$ & $37.5 \%$ & $45.8 \%$ & 4.29 & 0.743 \\
\hline i] Existing online retailers hove favorable retum policy & - & $16.7 \%$ & $52.1 \%$ & $18.8 \%$ & $12.5 \%$ & 3.27 & 0.893 \\
\hline Averaqe mean & & & & & & 3.78 & \\
\hline
\end{tabular}

\begin{tabular}{|c|c|c|c|c|c|c|c|}
\hline \multicolumn{8}{|l|}{ Social influence } \\
\hline i) Trust online shops that have received positive reviews from the authority & - & 6.390 & $16.7 \%$ & $45.8 \%$ & $31.3 \%$ & 4.02 & 0.863 \\
\hline i] Trust online shops that have received positive review from fomily \& friends & - & 4.29 & $31.3 \%$ & $33.3 \%$ & $31.3 \%$ & 3.92 & 0.895 \\
\hline Average mean & & & & & & 3.97 & \\
\hline \multicolumn{8}{|l|}{ Overall view towards online shopping } \\
\hline i) Online shopping is for individuals with high income & $14.6 \%$ & $31.3 \%$ & $31.3 \%$ & $10.4 \%$ & $12.5 \%$ & 2.75 & 1.212 \\
\hline i) Online shopping needs a skilful internet user & $4.2 \%$ & $12.5 \%$ & $16.7 \%$ & $50.0 \%$ & $16.7 \%$ & 3.63 & 1.044 \\
\hline iii) Online shopping is risky & - & $10.4 \%$ & $16.7 \%$ & $37.5 \%$ & $35.4 \%$ & 3.98 & 0.978 \\
\hline iv) Prefer traditional shopping as compared to online shopping & - & $10.4 \%$ & $29.2 \%$ & $41.7 \%$ & $18.8 \%$ & 3.69 & 0.903 \\
\hline v) Online shopping will eventually supersede traditional shopping & - & $20.8 \%$ & 29.29 & $41.7 \%$ & $8.3 \%$ & 3.38 & 0.914 \\
\hline vi) Local retailers should offer online shopping os an olternative & - & $4.2 \%$ & $22.9 \%$ & $37.5 \%$ & $35.4 \%$ & 4.04 & 0.874 \\
\hline Average mean & & & & & & 3.58 & \\
\hline
\end{tabular}


The perceptions of respondents regarding convenience brought up as result of online purchasing was determined based on three opinions, "Shopping online saves time", "It is a great advantage to shop anytime of the day" and "Online shopping reduces overall costs as compared to traditional shopping" with means of 3.96, 4.17 and 4.48 respectively. The average mean of convenience was 3.87 implying that online shopping enabled the respondents to shop anytime of the day, spent less time shopping and reduced overall cost of shopping. Hypothesis $\mathrm{H} 1 \mathrm{c}$ : is rejected which states that "There is a negative relationship between convenience risk and attitude towards online retailing". Respondents were of the opinion that online shopping will make shopping less time consuming and convenient (shop anytime of the day).

The four opinions considered regarding product delivery had an average mean of 3.48. The respondents expressed their feelings on the following issues "Purchase online only, if there is provision for home delivery (mean=3.67)"," Prefer to collect the product myself (mean=3.42)", "Long time is required for the delivery of products (mean=3.44)" and "Courier companies are reliable (mean=3.38)". The respondents were concerned about the delivery of the products they purchase online. Hypothesis $\mathrm{H} 2$ : is accepted, "The fear of product delivery will negatively affect attitudes towards online shopping".

Respondents expressed their opinions regarding online shopping return policy based on two factors "Purchase through online only, on condition of good return policy (mean=4.29)" and "Existing online retailers have favourable return policy (mean=3.27)". The average mean for return policy was 3.78 and this highlight the fact that respondents will shop online on condition of good return policy. Therefore Hypothesis H3: is accepted, "A good return policy will positively affect attitudes towards online shopping".

The view of respondents on Technology specific innovativeness was determined based on three issues, "Lack of internet use experience (mean=3.50), "Online shopping complex as compared to traditional shopping (mean=3.52)" and "Several resources required for online shopping (mean=3.48)". The average mean of technology specific innovativeness was 3.50 implying that the respondents were in agreement it was complicated to purchase online, internet experience was a necessity and there was need of several resources for online shopping. Hypothesis $\mathrm{H} 4$ : is rejected, "There is a negative relationship between technology specific innovativeness (TSI) and online retailing".

Social influence effect on purchasing online was determined based on two issues, "Trust online shops that have received positive reviews from the authority (mean=4.02)" and "Trust online shops that have received positive review from family and friends (mean=3.92)". 3.97 was the average mean of Social influence implying that respondents were influenced positively by good reviews from authorities, friends and family regarding online shops. Hypothesis H5: is accepted, "There is a positive relationship between subjective norms (opinion and decision of significant others such as relatives, friends, peers) and online retailing".

Perceptions regarding the overall view of respondents towards online shopping individually had a mean above the expected mean of 3.00 except for "Online shopping is for individuals with high income" that had a mean of 2.75. The respondents believed that anyone can make use of online shopping and an individual's social standing in the society was not a deterrent. The majority of the respondents were of the view that online shopping was risky (mean $=3.98$ ), however, it was supposed to be offered as shopping alternative to customers (mean $=4.04$ ) and required experienced internet users (mean $=3.63$ ). Nonetheless, the respondents preferred to use traditional shopping as compared online shopping (mean=3.69) although they were of the opinion that at some point online shopping will supersede 
Mashoko T. Dzimiri, Katlego A. Thamage, Mogotsinyana Mapharing, Elang Basuhi, Ishmael Radikoko; Consumer Perceptions towards Online Retailing in Botswana: A Case Study of the University of Botswana, Transactions on Networks and Communications, Volume 6 No. 5, October (2018); pp: 70-91

traditional shopping (mean $=3.38$ ). The overall view of respondents represented their attitude toward online shopping and based on the average mean of 3.58, respondents were of the opinion that although online retailing may seem risky and not preferred method of shopping at the moment gradually everyone will have to make use of it. Therefore Hypothesis H6: is accepted, "There is direct relationship between attitude and online retailing".

\section{Comparison of students and employees perceptions toward online shopping}

Table 3 shows a comparison of students and employees perceptions toward online shopping. Students had an average mean of 3.65 as compared to employees' average mean of 3.58 implying that students were more influenced by the perceptions considered in making a decision to purchase online. When an independent t-test was conducted for the means of the twenty six opinions considered for the students and employees, only one opinion "Local retailers should offer online shopping as an alternative" had statistically significant results with a $\mathrm{t}=2.429, \mathrm{p}<0.05$.

There was a significant difference in terms of opinion on whether local retailers should offer online shopping as an alternative. The students were of the opinion that online retailing should be offered as an alternative with a higher mean of 4.33 as compared to the mean of 3.75 for employees.

"Social influences" had the highest mean of 4.15 for students followed by "Return policy" with mean of 3.86. The other perceptions of students that had average means above 3.5 were Convenience (mean=3.73), Overall view towards online shopping (mean=3.72), Financial risk (mean=3.57) and Technology specific innovativeness (mean=3.503). Products delivery and products risk had average means of 3.49 and 3.36 respectively above the expected average mean of 3 .

For employees "Convenience" had the highest mean of 4 followed by "Social influence" with average mean of 3.80. The other perceptions that had higher average means for employees were Return policy (mean=3.71), Products risk (mean=3.58), Financial risk (mean=3.50) and Technology specific innovativeness (mean=3.50). Products delivery and Overall view (attitude) toward online shopping had average means of 3.46 and 3.43 respectively above the expected average mean of 3 . 
Table 3: Comparison of students and employees perceptions towards online shopping

\begin{tabular}{|c|c|c|c|c|c|c|}
\hline & \multicolumn{2}{|c|}{ Students } & \multicolumn{2}{|c|}{ Employees } & \multicolumn{2}{|c|}{ t-fest for equality of means } \\
\hline & Mean & Std. Dev & Mean & Std. Dev & $t$ & Significance \\
\hline \multicolumn{7}{|l|}{ Convenience } \\
\hline i) Shopping online saves time & 3.83 & 0.87 & 4.08 & 0.97 & $(0.939)$ & 0.353 \\
\hline i] It is a great advantoge to shop any time of the days & 4.08 & 0.65 & 4.25 & 0.79 & $(0.794)$ & 0.431 \\
\hline ii) Online shopping reduces overall costs as compared to traditional shopping & 3.29 & 1.04 & 3.67 & 0.92 & $(1.324)$ & 0.192 \\
\hline Average mean & 3.73 & & 4.00 & & & \\
\hline \multicolumn{7}{|l|}{ Products Risk } \\
\hline i) There is a broad selection of goods on the internet & 4.04 & 0.96 & 4.13 & 0.74 & $(0.338)$ & 0.737 \\
\hline i] The description of products on internet are accurate & 3.00 & 0.98 & 3.29 & 0.81 & $(1.127)$ & 0.266 \\
\hline ii) Available product information is sufficient to make a purchase & 3.04 & 1.08 & 3.33 & 1.05 & $(0.948)$ & 0.348 \\
\hline Average mean & 3.36 & & 3.58 & & & \\
\hline \multicolumn{7}{|l|}{ Financial Risk } \\
\hline i) Online shopping is as secure as traditional shopping & 2.63 & 1.17 & 3.13 & 1.36 & $(1.363)$ & 0.179 \\
\hline i] Hesitate to disclose credit/debit card detals during online shopping & 3.83 & 1.20 & 3.67 & 1.27 & 0.466 & 0.644 \\
\hline iii) Prefer cosh on delivery than poyment using credit/debit card & 4.25 & 1.19 & 3.71 & 1.27 & 1.527 & 0.134 \\
\hline Average mean & 3.57 & & 3.50 & & & \\
\hline \multicolumn{7}{|l|}{ Products delivery } \\
\hline i) Purchose online only if there is provision for home delivery & 3.92 & 0.88 & 3.42 & 1.21 & 1.634 & 0.109 \\
\hline i] Prefer to collect the product myself & 3.17 & 1.13 & 3.67 & 1.05 & $(1.589)$ & 0.119 \\
\hline iii) Long time required for the delivery of products & 3.63 & 0.97 & 3.25 & 1.19 & 1.198 & 0.237 \\
\hline iv) Courier companies are reliable & 3.25 & 1.11 & 3.50 & 0.93 & $(0.843)$ & 0.403 \\
\hline Average mean & 3.49 & & 3.46 & & & \\
\hline
\end{tabular}

\begin{tabular}{|c|c|c|c|c|c|c|}
\hline \multicolumn{7}{|l|}{ Technology specific innovativeness } \\
\hline i) Lack of intemet use experience & 3.460 & 1.179 & 3.540 & 0.977 & $(0.267)$ & 0.791 \\
\hline i) Online shopping complex compore to traditional shopping & 3.630 & 1.013 & 3.420 & 0.929 & 0.742 & 0.462 \\
\hline iii) Several resources required for online shopping & 3.420 & 1.100 & 3.540 & 0.884 & $(0.434)$ & 0.666 \\
\hline Average mean & 3.503 & & 3.500 & & & \\
\hline \multicolumn{7}{|l|}{ Refurn policy } \\
\hline i) Purchose through online only, on condition of good return policy & 4.46 & 0.66 & 4.13 & 0.80 & 1.580 & 0.121 \\
\hline i] Existing online retailers hove favorable retum policy & 3.25 & 0.79 & 3.29 & 1.00 & $(0.160)$ & 0.874 \\
\hline Average mean & 3.86 & & 3.71 & & & \\
\hline \multicolumn{7}{|l|}{ Social influence } \\
\hline i) Trust online shops that have received positive reviews from the authority & 4.13 & 0.95 & 3.92 & 0.78 & 0.834 & 0.409 \\
\hline i] Trust online shops that have received positive review from fomily \& friends & 4.17 & 0.96 & 3.67 & 0.76 & 1.995 & 0.052 \\
\hline Average mean & 4.15 & & 3.80 & & & \\
\hline \multicolumn{7}{|l|}{ Overall view towards online shopping } \\
\hline i) Online shopping is for individuals with high income & 2.79 & 1.10 & 2.71 & 1.33 & 0.236 & 0.815 \\
\hline i) Online shopping needs a skilful internet user & 3.83 & 1.05 & 3.42 & 1.02 & 1.396 & 0.169 \\
\hline iii) Online shopping is risky & 4.17 & 0.82 & 3.79 & 1.10 & 1.339 & 0.188 \\
\hline iv) Prefer traditional shopping as compared to online shopping & 3.83 & 0.92 & 3.54 & 0.88 & 1.122 & 0.268 \\
\hline v) Online shopping will eventually supersede traditional shopping & 3.38 & 1.01 & 3.38 & 0.82 & 0 & 1.000 \\
\hline vi) Local retailers should offer online shopping os an alternative & 4.33 & 0.76 & 3.75 & 0.90 & 2.429 & 0.019 \\
\hline Average mean & 3.72 & & 3.43 & & & \\
\hline Overall average mean & 3.65 & & 3.58 & & 0.245 & 0.384 \\
\hline
\end{tabular}

The independent t-test results for the twenty six perceptions considered for the students and employees were insignificant $(p>0.05)$ except for one perception "Local retailers should offer online shopping as an alternative". The average $t$-test score for all the perceptions was $t=0.245, p>0.05$. This implies that there was an insignificant difference amongst the means of the perceptions influencing students and employees to purchase online. Therefore hypothesis H7a: is rejected which states that "Older generations (staff) are 
Mashoko T. Dzimiri, Katlego A. Thamage, Mogotsinyana Mapharing, Elang Basuhi, Ishmael Radikoko; Consumer Perceptions towards Online Retailing in Botswana: A Case Study of the University of Botswana, Transactions on Networks and Communications, Volume 6 No. 5, October (2018); pp: 70-91

perceived to use more online retailing than younger ones (students)" because employees and students opinions regarding the use of online purchasing were more or less the same.

\section{Comparison of males and females perceptions toward online shopping}

Table 4 shows a comparison of males and females perceptions toward online shopping. Males had an average mean of 3.64 as compared to females' average mean of 3.59 implying that males were more influenced by the factors considered in making a decision to purchase online as compared to females. When an independent $t$-test was conducted for the means of the twenty six opinions considered they all had statistically insignificant results.

Convenience had an equal average mean of 3.87 for both groups implying that the perceptions of both males and females were the same regarding the convenience of using online retailing. There were no major differences in terms of average means for "Financial risk", "Return policy" and "Product delivery" implying that their perceptions towards the three factors were almost the same for both groups.

Reasonable differences were noticed for the average means of "Technology specific innovativeness" males had an average mean of 3.31 whilst their female counterparts had 3.71 and "Social influences" in which males had an average mean 4.14 and females an average mean of 3.79 .

The independent $\mathrm{t}$-test results for the twenty six perceptions considered for the males and females were insignificant $(p>0.05)$. The average $t$-test score for all the perceptions was $t=0.182, p>0.05$. This implies that there was an insignificant difference amongst the means of the perceptions influencing males and females to purchase online. Therefore hypothesis $\mathrm{H} 7 \mathrm{~b}$ : is rejected which states that "Males are perceived to use more online retailing than female counterparts" because males and females perceptions towards the use of online purchasing were almost the same.

Table 4: Comparison of males and females perceptions toward online shopping

\begin{tabular}{|c|c|c|c|c|c|c|}
\hline & \multicolumn{2}{|c|}{ Male } & \multicolumn{2}{|c|}{ Female } & \multicolumn{2}{|c|}{ t-test for equality of means } \\
\hline & Mean & Std. Dev & Mean & Std. Dev & $t$ & Significance \\
\hline \multicolumn{7}{|l|}{ Convenience } \\
\hline i) Shopping online saves time & 3.84 & 0.987 & 4.09 & 0.848 & $(0.926)$ & 0.359 \\
\hline ii) It is a great advantage to shop any time of the days & 4.16 & 0.746 & 4.17 & 0.717 & $(0.066)$ & 0.948 \\
\hline iii) Onine shopping reduces overall costs as compared to traditional shopping & 3.60 & 1.00 & 3.35 & 0.98 & 0.880 & 0.383 \\
\hline Average mean & 3.87 & & 3.87 & & & \\
\hline \multicolumn{7}{|l|}{ Products Risk } \\
\hline i) There is a broad selection of goods on the internet & 4.12 & 0.78 & 4.04 & 0.93 & 0.310 & 0.758 \\
\hline ii) The description of products on internet are accurate & 3.32 & 0.80 & 2.96 & 0.98 & 1.414 & 0.164 \\
\hline iii) Available product information is sufficient to make a purchase & 3.24 & 1.13 & 3.13 & 1.01 & 0.353 & 0.726 \\
\hline Average mean & 3.56 & & 3.38 & & & \\
\hline \multicolumn{7}{|l|}{ Financial Risk } \\
\hline i) Online shopping is as secure as traditional shopping & 3.04 & 1.24 & 2.70 & 1.33 & 0.928 & 0.358 \\
\hline ii) Hesitate to disclose credit/debit card detals during online shopping & 3.76 & 1.17 & 3.74 & 1.32 & 0.058 & 0.954 \\
\hline iii) Prefer cosh on delivery than payment using credit/debit card & 3.76 & 1.33 & 4.22 & 1.13 & $(1.279)$ & 0.207 \\
\hline Average mean & 3.52 & & 3.55 & & & \\
\hline \multicolumn{7}{|l|}{ Products delivery } \\
\hline i) Purchose online only if there is provision for home delivery & 3.52 & 1.12 & 3.83 & 1.03 & $(0.982)$ & 0.331 \\
\hline ii) Prefer to collect the product myself & 3.56 & 0.87 & 3.26 & 1.32 & 0.933 & 0.355 \\
\hline iii) Long time required for the delivery of products & 3.64 & 0.95 & 3.22 & 1.20 & 1.354 & 0.182 \\
\hline iv) Courier companies are reliable & 3.20 & 1.12 & 3.57 & 0.90 & $(1.242)$ & 0.221 \\
\hline Average mean & 3.48 & & 3.47 & & & \\
\hline
\end{tabular}




\begin{tabular}{|c|c|c|c|c|c|c|}
\hline \multicolumn{7}{|l|}{ Technology specific innovativeness } \\
\hline i) Lock of intemet use experience & 3.32 & 1.145 & 3.70 & 0.974 & $(1.219)$ & 0.229 \\
\hline i) Online shopping complex compore to traditional shopping & 3.32 & 1.03 & 3.74 & 0.864 & $(1.520)$ & 0.135 \\
\hline iii) Several resources required for online shopping & 3.28 & 1.021 & 3.70 & 0.926 & $(1.472)$ & 0.148 \\
\hline Average mean & 3.31 & & 3.71 & & & \\
\hline \multicolumn{7}{|l|}{ Return policy } \\
\hline i) Purchase through online only on condition of good return policy & 4.28 & 0.74 & 4.30 & 0.77 & $(0.112)$ & 0.911 \\
\hline i] Existing online retailers have favorable return policy & 3.40 & 1.00 & 3.13 & 0.76 & 1.046 & 0.301 \\
\hline Average mean & 3.84 & & 3.72 & & & \\
\hline \multicolumn{7}{|l|}{ Social influence } \\
\hline i) Trust online shops that have received positive reviews from the authority & 4.16 & 0.80 & 3.87 & 0.92 & 1.170 & 0.248 \\
\hline i] Trust online shops that have received positive review from fomily \& friends & 4.12 & 0.78 & 3.70 & 0.97 & 1.672 & 0.101 \\
\hline Average mean & 4.14 & & 3.79 & & & \\
\hline \multicolumn{7}{|l|}{ Overall view towards online shopping } \\
\hline i) Online shopping is for individuals with high income & 3.00 & 1.23 & 2.48 & 1.16 & 1.511 & 0.138 \\
\hline i) Online shopping needs a skilful internet user & 3.76 & 0.97 & 3.48 & 1.12 & 0.933 & 0.356 \\
\hline iii) Onine shopping is risky & 3.88 & 1.05 & 4.09 & 0.90 & $(0.729)$ & 0.470 \\
\hline iv) Prefer traditional shopping as compared to online shopping & 3.80 & 0.91 & 3.57 & 0.90 & 0.898 & 0.374 \\
\hline v) Online shopping will eventually supersede traditional shopping & 3.52 & 0.87 & 3.22 & 0.95 & 1 & 0.256 \\
\hline vi) Local retailers should offer online shopping os an alternative & 4.00 & 0.96 & 4.09 & 0.79 & $(0.341)$ & 0.735 \\
\hline Average mean & 3.66 & & 3.49 & & & \\
\hline Overall average mean & 3.64 & & 3.59 & & 0.182 & 0.398 \\
\hline
\end{tabular}

Table 5: Summary of accepted/rejected hypothesis.

\begin{tabular}{|c|c|c|}
\hline Hypothesis & Statement & Result \\
\hline $\mathrm{Ho}_{1 \mathrm{a}} \mathrm{:}$ & $\begin{array}{l}\text { There is a negative relationship between financial risk and attitude } \\
\text { towards online retailing }\end{array}$ & Accepted \\
\hline $\mathrm{Ho}_{1 \mathrm{~b}}:$ & $\begin{array}{l}\text { There is a negative relationship between product risk and attitude } \\
\text { towards online retailing }\end{array}$ & Rejected \\
\hline $\mathrm{Ho}_{1 \mathrm{c}}:$ & $\begin{array}{l}\text { There is a negative relationship between convenience risk and attitude } \\
\text { towards online retailing }\end{array}$ & Rejected \\
\hline $\mathrm{Ho}_{2}:$ & $\begin{array}{l}\text { The fear of product delivery will negatively affect attitudes towards } \\
\text { online shopping }\end{array}$ & Accepted \\
\hline $\mathrm{Ho}_{3}:$ & $\begin{array}{l}\text { A good return policy will positively affect attitudes towards online } \\
\text { shopping }\end{array}$ & Accepted \\
\hline $\mathrm{Ho}_{4}:$ & $\begin{array}{l}\text { There is a positive relationship between technology specific } \\
\text { innovativeness (TSI) and online retailing }\end{array}$ & Rejected \\
\hline Hos: & $\begin{array}{l}\text { There is a positive relationship between subjective norms (opinion and } \\
\text { decision of significant others such as relatives, friends, peers) and online } \\
\text { retailing }\end{array}$ & Accepted \\
\hline $\mathrm{Ho}_{6}:$ & There is direct relationship between attitude and online retailing & Accepted \\
\hline $\mathrm{Ho}_{7 \mathrm{a}} \mathrm{:}$ & $\begin{array}{l}\text { Older generations (staff) are perceived to use more online retailing than } \\
\text { younger ones (students) }\end{array}$ & Rejected \\
\hline $\mathrm{HO}_{7 \mathrm{~b}}$ : & $\begin{array}{l}\text { Males are perceived to use more online retailing than female } \\
\text { counterparts }\end{array}$ & Rejected \\
\hline
\end{tabular}


Mashoko T. Dzimiri, Katlego A. Thamage, Mogotsinyana Mapharing, Elang Basuhi, Ishmael Radikoko; Consumer Perceptions towards Online Retailing in Botswana: A Case Study of the University of Botswana, Transactions on Networks and Communications, Volume 6 No. 5, October (2018); pp: 70-91

\section{Conclusion and Recommendations}

The paper set out to establish the factors influencing or deterring consumers to purchase from online retailing stores in Botswana. Specific focus was on identifying and assessing the existing customer perceptions towards online retailing among University of Botswana students and employees. We adopted the modified Theory of Planned Behavior (TPB) particularly used by [11] as our conceptual framework. The model assumes that online shopping behavior is influenced by several factors, the four most common being attitude, subjective norm, perceived behavioral control and technology specific innovativeness.

The expectation was that the way consumers perceived financial risk in terms of online shopping has a direct impact on the decision to partake in online retailing. The results of this study are in line with literature [23] that found that the higher the percieved financial risks the more unlikely it is for consumers to take part in online retailing. When consumers choose to buy products online there is an expectation that the product displayed and received match the given description. Researchers have differents opinions regarding the impact of product risk on consumers decisions to carry out online retailing. However results of this study indicate that users are not deterred by perceived product risk. One of the reasons consumers choose online retailing over traditional methods is the convenience offered by these platforms. On the other hand, some Internet shoppers may hesitate to shop online due to concerns about inconvenience or delays in receiving merchandise [40]. In this particular study the results indicate that consumers believe online retailing is more favourable because of its potential to being more convenient this is in line with the findings of $[42,43]$.

In developing countries such as Botswana, internet accessibility is not fully established and is often expensive. These concerns as similar to those of consumers in India ultimately affect use and support of online retailing stores. Furthermore, there is the aspect of delivery which encompasses all the concerns associated with delivery of the product ordered, such as shipping fees, delayed delivery and/or not receiving a product ordered [11]. It is no wonder the results of this study indicate that product delivery plays a major role in their decision to shop online. Consumer's attitude towards online retailing is also influenced by retailers having a good return policy in place to easily allow consumers to return goods if dissatisfied. Not everyone is comfortable or conversant with online retailing hence the results of this study support the view that those uncomfortable with the use of a computer will likely find shopping at a traditional store easier and faster than through online retailing sites[50]. The results also confirm the fact that many consumers rely on reviews or recommendations from other customers which is in line with the findings of [23], in their study they noted that consumer buying decisions are highly affected by the opinions and decisions of others.

In the context of online shopping, [17] consider attitudes to be the consumers' positive or negative feelings related to accomplishing the purchasing behavior on the internet. The respondents of this study do not have a negative attitude towards online shopping despite the fact many currently use the traditional method of shopping in physical stores. Instead consumers have an appreciation that online retailing will eventually be the preferred method of shopping. There is a difference in opinion among researchers regarding demographic factors such as age and gender on online retailing. Findings by [59] found that older generation were more likely to participate in online retailing while [40] note that age was found to be a predictor of amount spent online; this is not in line with the findings of this study that age 
plays an insignificant role in consumers choice in participating in online retailing. In another study by [56], concluded that gender had no significant influence on shopping behavior which is in line with the findings of this study that found that gender plays an insignifant role on online retailing.

As part of recommendations we suggest that local retailers provide online retailing as an alternative method of shopping, as there is still opportunity for growth in the Botswana market based on the results of this study. Future research can be carried out beyond the University of Botswana community to assess consumer perceptions towards online retailing at a national level.

Local retailers should aim to fully integrate both the physical and virtual stores in order to give consumers a seamless experience. This includes offering a wide variety of products, providing online and after sales support. Delivery costs and the time period between placing an order and receiving the goods is also an essential component of online retailing that often deters consumers from completing an online purchase [38]. In addition retailers should ensure that they provide a secure platform in order to build trust between themselves and consumers by protecting customer details such as personal credentials and credit card details; this way reducing the perceived risk associated with online retailing.

\section{REFERENCES}

[1] Fallows, J., The 50 greatest breakthroughs since the wheel. The Atlantic, 2013. 3.

[2] Macdougald, J.J., Internet Use and Economic Development: Evidence and Policy Implications, 2011, University of South Florida Scholar Commons: South Florida.

[3] Ajeet, K., E-commerce Basics: Advantages and Disadvantages of Ecommerce, 2014.

[4] eMarketer, in eMarketer Inc.2014.

[5] Zaczkiewicz, A., Amazon, Wal-Mart lead top 25 e-commerce retail list. WWD, March, 2016. 7.

[6] Li, C., China Online Payment Market Overview for 2014. China Internet Watch, 2014.

[7] Gensler, L., The world's largest retailers 2016: Wal-mart dominates but amazon is catching up. Retrieved from Forbes website: http://www. forbes. com/sites/laurengensler/2016/05/27/global-2000worldslargest-retailers, 2016.

[8] Botswana, s., Botswana Household access and individual use of Information and Communication Technologies- 2014, 2016, Statistics Botswana: Gaborone.

[9] Deloitte. Deloitte Touche Tohmatsu Limited, 2015.

[10] Population \& Housing Census 2011, 2015, Statistics Botswana: Gaborone.

[11] Sinha, J. and J. Kim, Factors affecting Indian consumers' online buying behavior. Innovative Marketing, 2012. 8(2): p. 46-57.

[12] Ajzen, l., The theory of planned behavior. Organizational behavior and human decision processes, 1991. 50(2): p. 179-211. 
Mashoko T. Dzimiri, Katlego A. Thamage, Mogotsinyana Mapharing, Elang Basuhi, Ishmael Radikoko; Consumer Perceptions towards Online Retailing in Botswana: A Case Study of the University of Botswana, Transactions on Networks and Communications, Volume 6 No. 5, October (2018); pp: 70-91

[13] Munnukka, J., Customers' purchase intentions as a reflection of price perception. Journal of Product \& Brand Management, 2008. 17(3): p. 188-196.

[14] Cheung, C.M. and M.K. Lee, An integrative model of consumer trust in internet shopping. ECIS 2003 Proceedings, 2003: p. 48.

[15] Wu, S.-I., The relationship between consumer characteristics and attitude toward online shopping. Marketing intelligence \& planning, 2003. 21(1): p. 37-44.

[16] Grandom, E. and P. Mykytyn, Theory-based Instrumentation to Measure the Intention to use Electronic Commerce in Small and Medium Sized Businesses. Journal of Computer Information Systems, 2004: p. 4457.

[17] Chiu, Y.-B., C.-P. Lin, and L.-L. Tang, Gender differs: assessing a model of online purchase intentions in etail service. International journal of service industry management, 2005. 16(5): p. 416-435.

[18] Armstrong, G. and P. Kotler, Marketing-An Introduction, (2000), Pearson Education, Asia.

[19] Delafrooz, N., et al., Factors affecting students' attitude toward online shopping. African Journal of Business Management Vol. 3(5), 2009: p. 200-209.

[20] Lawrence, W.W., Of acceptable risk. William Kaufmann, Los Altos, CA, 1976.

[21] Standardization, I.O.f., ISO 31000: Risk Management: Principles and Guidelines. 2009: ISO.

[22] Bauer, R.A. Consumer behavior as risk taking. in Proceedings of the 43rd National Conference of the American Marketing Assocation, June 15, 16, 17, Chicago, Illinois, 1960. 1960. American Marketing Association.

[23] Arshad, A., et al., The Impact of Perceived Risk on Online Buying Behavior. International Journal of New Technology and Research (IJNTR) ISSN, 2015: p. 2454-4116.

[24] Bhatnagar, A. and S. Ghose, Segmenting consumers based on the benefits and risks of Internet shopping. Journal of Business Research, 2004. 57(12): p. 1352-1360.

[25] Doolin, B., et al., Perceived risk, the Internet shopping experience and online purchasing behavior: A New Zealand perspective. Journal of Global Information Management (JGIM), 2005. 13(2): p. 66-88.

[26] Kuhlmeier, D. and G. Knight, Antecedents to internet-based purchasing: a multinational study. International Marketing Review, 2005. 22(4): p. 460-473.

[27] Adams, J., Managing Risk: framing your problems. BoeringerIngelheim Alumni, 2014.

[28] Jacoby, K. Leon. The Components of Perceived Risk Proceedings. 1972. Third Annual Conference Association for Consumer Research. Chicago: University of Chicago.

[29] Horton, R.L., The structure of perceived risk: Some further progress. Journal of the Academy of Marketing Science, 1976. 4(4): p. 694-706. 
[30] Dai, B., S. Forsythe, and W.-S. Kwon, The impact of online shopping experience on risk perceptions and online purchase intentions: does product category matter? Journal of Electronic Commerce Research, 2014. 15(1): p. 13.

[31] Jacoby, J. and J.C. Olson, Consumer response to price: An attitudinal information processing perspective, in Moving ahead in attitudinal research. 1977, American Marketing Association: Chicago.

[32] Chiang, K.-P. and R.R. Dholakia, Factors Driving Consumer Intention to Shop Online: An Empirical Investigation. Journal of Consumer Psychology Vol.13(1\&2), 2003: p. 177-183.

[33] Heim, G.R. and K.K. Sinha, Operational drivers of customer loyalty in electronic retailing: An empirical analysis of electronic food retailers. Manufacturing \& Service Operations Management, 2001. 3(3): p. 264271.

[34] Egeln, L.S. and J.A. Joseph, Shopping cart abandonment in online shopping. Atlantic Marketing Journal, 2012. 1(1): p. 1.

[35] Bhatnagar, A., S. Misra, and H.R. Rao, On Risk, Convenience and Internet Shopping Behavior. Communications of the ACM (Association for Computing Machinery) Vol. 43(11), 2000: p. 98-105.

[36] Akbar, S. and P.T. James, Consumers' attitude towards online shopping Factors influencing employees of crazy domains to shop online. Journal of Management and Marketing Research, 2014. 14: p. 1.

[37] Kesh, S., S. Ramanujan, and S. Nerur, A framework for analyzing e-commerce security. Information Management \& Computer Security, 2002. 10(4): p. 149-158.

[38] Bhatnagar, A., S. Misra, and H.R. Rao, On risk, convenience, and Internet shopping behavior. Communications of the ACM, 2000. 43(11): p. 98-105.

[39] Chapell, A., Eye on privacy. Target Marketing, 2005. 28(10): p. 27.

[40] Forsythe, S. and B. Shi, Consumer Patronage and Risk Perceptions in Internet Shopping. Journal of Business Research Vol.56, 2003: p. 867-875.

[41] Peter, J.P. and L.X. Tarpey, A Comprehensive Analysis Three Consumer Decision Strategies. Journal of Consumer Research Vol. 2, 1975: p. 29-37.

[42] Delhagen, Retailer revs up, 1997. p. 4.

[43] Jarvenpaa, S.L. and P.A. Todd, Is there a future for retailing on the Internet. Electronic marketing and the consumer, 1997. 1(12): p. 139-154.

[44] Teo and S.H. Thompson, Attitude toward online shopping and the Internet. Behavior and Information Technology Vol. 21(4), 2002: p. 259-271.

[45] Cheema, A. and A.M. Kaikati, The effect of need for uniqueness on word of mouth. Journal of Marketing Research, 2010. 47(3): p. 553-563.

[46] Ajzen, I., The Theory of Planned Behavior. Organizational Behavior and Human Decision Processes, 1991: p. 179-211. 
Mashoko T. Dzimiri, Katlego A. Thamage, Mogotsinyana Mapharing, Elang Basuhi, Ishmael Radikoko; Consumer Perceptions towards Online Retailing in Botswana: A Case Study of the University of Botswana, Transactions on Networks and Communications, Volume 6 No. 5, October (2018); pp: 70-91

[47] Khatimah, H. and F. Halim, The effect of attitude and its decomposed, perceived behavioral control and its decomposed and awareness on intention to use e-money mobile in Indonesia. Journal of Scientific Research and Development, 2016: p. 39-50.

[48] Sultan, F. and R.B. Henrichs, Consumer preferences for Internet services over time: initial explorations. Journal of consumer marketing, 2000. 17(5): p. 386-402.

[49] George, J.F., The theory of planned behavior and Internet purchasing. Internet research, 2004. 14(3): p. 198-212.

[50] Monsuwe, T.P.y., B.G.C. Dellaert, and K.d. Ruyter, What drives consumers to shop online? A literature review. International Journal of Service Industry Management, 2004.

[51] Heskett, J.L., et al., Putting the service-profit chain to work. Harvard business review, 1994. 72(2): p. 164174.

[52] Korgaonkar, P.K. and L.D. Wolin, A multivariate analysis of web usage. Journal of advertising research, 1999. 39: p. 53-68.

[53] Wan, Y., M. Nakayama, and N. Sutdiffe, The Impact of age and shopping experiences on the classification of search, experience, and credence goods in online shopping. Journal of Information Systems, 2012: p. 135-148.

[54] Graeff, T.R. and S. Harmon, Collecting and using personal data: consumers' awareness and concerns. Journal of consumer marketing, 2002. 19(4): p. 302-318.

[55] Milne, G.R. and A.J. Rohm, Consumer privacy and name removal across direct marketing channels: Exploring opt-in and opt-out alternatives. Journal of Public Policy \& Marketing, 2000. 19(2): p. 238-249.

[56] Stafford, T.F., A. Turan, and M.S. Raisinghani, International and cross-cultural influences on online shopping behavior. Journal of Global Information Technology Management, 2004. 7(2): p. 70-87.

[57] Donthu, N. and A. Garcia, The internet shopper. Journal of advertising research, 1999. 39(3): p. 52-52.

[58] Thompson, B., The selling of the clickeati: Today's kids have a visceral connection to computers, in Now the shopping Gods are starting to connect as well. 1999, Wash Post.

[59] Sorce, P., V. Perotti, and S. Widrick, Attitude and age differences in online buying. International Journal of Retail \& Distribution Management, 2005. 33(2): p. 122-132.

[60] Giantari, G.A.K., et al., The role of perceived behavioral control and trust as mediator of experience on online purchasing intentions relationship: A study on youths in Denpasar City (Indonesia). International Journal of Business and Management Invention Vol.2 (1), 2013: p. 30-38.

[61] Kwon, W.-S. and M. Noh, The influence of prior experience and age on mature consumers' perceptions and intentions of internet apparel shopping. Journal of Fashion Marketing and Management: An International Journal, 2010. 14(3): p. 335-349. 
[62] Weisberg, J., D. Te'eni, and L. Arman, Past purchase and intention to purchase in e-commerce: The mediation of social presence and trust. Internet research, 2011. 21(1): p. 82-96.

[63] Giantari, I., et al., The role of perceived behavioral control and trust as mediator of experience on online purchasing intentions relationship a study on youths in denpasar city (Indonesia). International Journal of Business and Management Invention, 2013. 2(1): p. 30-38.

[64] Saunders, M., P. Lewis, and A. Thornhill, Research methods for business students. 2007. England: Pearson Education Limited, 2009.

[65] Bryman, A. and E. Bell, Business research methods. 2015: Oxford University Press, USA. 